\title{
JURIDICAL PROBLEMATIC ON SUPERVISION OF JUDGES IN THE CONSTITUTIONAL SYSTEM OF REPUBLIC OF INDONESIA
}

\author{
Muhammad Fauzan \\ Faculty of Law Universitas Jenderal Soedirman \\ E-mail: fauzanhtn@yahoo.co.id
}

\begin{abstract}
The presence of the Judicial Commission in the constitutional system of Republic of Indonesia is mandated by the 1945 Constitution, which in the execution of their duties and functions has provoked a variety of opinions, especially related to the supervision of judges who are considered to threaten the independence of the judicial power. Based on the results of discussion it is concluded that the juridical problematic which happens to the supervision of judges in the constitutional system of Republic of Indonesia which are: first, unclear formulation of Article 24B of 1945 Constitution, especially related with the other authority of the Judicial Commission in order to preserve and enforce the honor, dignity, and the behavior of judges; second, it is related with the disharmony and inconsistency legislation regulations that controlling the supervision of judges; third, it is related to the institutional organization of the Judicial Commission; and fourth, it is related to the vagueness of the definition of supervision.
\end{abstract}

Keywords: juridical problematic, supervision of judges, Indonesia

\section{Abstrak}

Kehadiran Komisi Yudisial dalam sistem ketatanegaraan Republik Indonesia merupakan amanat dari Undang Undang Dasar 1945, dimana dalam pelaksanaan tugas pokok dan fungsinya telah menimbulkan berbagai pendapat khususnya terkait dengan pengawasan hakim yang dianggap dapat mengancam kemandirian kekuasaan kehakiman. Berdasarkan hasil pembahasan disimpulkan bahwa problematik yuridis yang terjadi pada pengawasan hakim dalam sistem ketatanegaraan Republik Indonesia meliputi: pertama, ketidak jelasan rumusan Pasal 24B UUD 1945 khususnya yang berkaitan dengan wewenang lain Komisi Yudisial dalam rangka menjaga dan menegakkan kehormatan, keluhuran martabat, serta perilaku hakim; kedua, berkaitan dengan disharmonisasi dan inkonsistensi peraturan perundang-undangan yang mengatur tentang pengawasan hakim; ketiga, berkaitan dengan organisasi kelembagaan Komisi Yudisial; dan keempat, berkaitan dengan ketidakjelasan pendefinisian tentang pengawasan.

Kata kunci: problematik, pengawasan hakim, Indonesia

Introduction

Before Constitution was amended, the provisions of the judicial power is an independent power which mandated by the Article 24 and 25 which states that "Judicial Power is an independent power, it means that apart from the influence of government...". Then the third amendment of the 1945 Constitution, the provision of independent power is no longer listed in the explanation, but it became the substance of Article 24 which states that "judicial power is an independent power to organize judicial administration to uphold the law and justice".
Hans Kelsen in the Pure Theory of Law noted the importance of an independent judicial power and independent from the influence of other powers. Hans Kelsen's argument consisted into 4 (four) terms Rechtsstaat: ${ }^{1}$ first, making process of regulation is by the parliament. The member of parliament is chosen directly by the Judicial Commission; second, mechanism of accountability for policies and actions taken by

\footnotetext{
Hans Kelsen, Pure Theory of Law, 1967, page 313 in Denny Indrayana, "Negara Hukum Indonesia Pasca Soeharto: Transisi Menuju Demokrasi vs Korupsi”, Jurnal Konstitusi, Vol. 1 No. 1, July 2004, Jakarta: Constitutional Court, page 106.
} 
the country's elite; third, State guarantees the independence of judicial power; and fourth, State protect human rights. ${ }^{2}$

In the author's view, the independent judicial power which is free from the influence of other powers include government power and also capitalist power/capital or extremely "power of money". Because in the practice, the rule has "dominant" affect "the upright" of the law of the state. We should remember, some acronyms often "spoofed" to insinuate that justice could be "bought", such as the Indonesian Criminal Code which should mean Kitab Undang-Undang Hukum Pidana (KUHP), "spoofed" to "Kalau ada Uang Habis Perkara (Money can end a case)".

The inclusion of a special chapter of the Judicial Commission authority to the Judicial Authority which there are Supreme Court and the Constitutional Court, made the position of the judicial power become interfered with by the executive power of the Judicial Commission. ${ }^{3}$ Judicial Power is not absolute, the things that can be seen in the Constitutional Court Provision Number 005/PUU-IV/2006 confirming that the independence of judicial authority or court should not be interpreted in absolute terms. Therefore, since the beginning of the idea of the amendment of the 1945 Constitution was a realization that as the independence ballast and to maintain the authority of the judicial power, it needs to be held external monitoring in the field of judicial ethics like in some countries, namely the establishment of the Judicial Commission, in addition to the internal controller by the Supreme Court itself, which is implemented by the Deputy Chief of supervision and control Agency. ${ }^{4}$ Based on those reasons, this paper will discuss about juridical problematic of judge supervision in the constitutional system of Republic of Indonesia.

2 Franz Magnis Suseno, 1993, Etika Politik: Prinsip Moral Dasar Kenegaraan Modern, Jakarta: Gramedia, page 298301.

3 Binsar M. Gultom, "Hormati Independensi Badan Peradilan”, Varia Peradilan Majlah Hukum, Year XXX No. 350, January 2015, Jakarta: IKAHI, page 62.

4 Nurhadi, "Bunga Rampai: Independesi Peradilan dan Imunitas Yudisial Hakim Yang Terancam", Varia Peradilan Majalah Hukum, Year XXVII No. 331, June 2013, Jakarta: IKAHI, 2013, page 99.

\section{Discussion}

The enactment of Law Number 22 Year 2004 concerning Judicial Commission with authority to oversee the conduct of judges as external oversight, has given rise to conflict of law, this is due at the time of the enactment of Law Number 22 Year 2004 there were still some laws that give authority to supervise the conduct of judges to institution or body other than the Judicial Commission. It can be seen from several laws such as the Law Number 14 Year 1985 concerning Supreme Court and Law Number 4 Year 2004 concerning Judicial Power.

UU Number 22 Year 2004 concerning Judicial Commission and Law Number 4 Year 2004 concerning Judicial Power is equally governing the supervision of the conduct of judges where such authority is given to agencies of different countries, if the Law Number 14 Year 1985 concerning Supreme Court provides oversight authority over the conduct of judges to the Supreme Court, while Law Number 22 Year 2004 concerning Judicial Commission and the Law Number 4 Year 2004 concerning Judicial Power provides the authority to supervise the conduct of judges to the Judicial Commission, indeed in doctrine known their maxim or principle that the new law overrule the old ones (lex posteriori derogat lex priori), but in practice the principle was not always understood and implemented by the parties in the constitutional system. Some juridical problematic related to the supervision of judges in law system are describe below.

\section{Unclear formulation of Article 24B paragraph} (1) on Amendment of the 1945 Constitution

Under the provisions of Article 24B of the amendment of the 1945 constitution can be argued that the authority of the Judicial Commission have only 2 (two) authorities which is constitutionally mandated in the amendment of the 1945 Constitution: first, proposing justices; and second, other authorities in order to preserve and uphold the honor, dignity, and behavior of judges. In addition, it can also be concluded that the composition, status and membership of 
the Judicial Commission shall be further regulated by law.

The other sentence authorities in order to preserve and uphold the honor, dignity and behavior of judges mandated in Article 24B paragraph (1) of the 1945 constitution. In practice, it has been understood that the presence of the Judicial Commission as a new state agency in the constitutional system is the institution in charge "supervise" the behavior of judges, because if the behavior of judges can be monitored, the desired positive impact for the judge to behave that reflects the nobility and dignity as a court.

As Institution, which has the authority to supervise the behavior of judges, it is not wrong if the person stated that the Judicial Commission has the higher "position"/principal of supervised institutions, in this case the judges as the representation of Supreme Court as an institution of judges power holders. In fact, the position of Judicial Commission structurally is equal to the Supreme Court and the Constitutional Court. However, the functional role of the Judicial Commission as a support (auxiliary) to the institution of judicial power. ${ }^{5}$

In the Law Number 22 Year 2004 concerning Judicial Commission has a debate relating with the interpretation of the word "judge" in Article 24B paragraph (1) whether the judge are refers to all judges, both of judge and other judges under the Supreme Court? or even including constitutional judge?

As described above, that the root problem of this debate is partly due to the unclear formulation of Article 24B paragraph (1) of the 1945 Constitution, and it is well known that the Constitution as written law supreme surely only contain issues that are fundamental, therefore the further arrangement in organic regulation.

\section{Disharmony and inconsistency of Regulation Legislation}

\footnotetext{
5 Jimly Asshiddiqie, 2006, Perkembangan dan Konsolidas Lembaga Negara Pasca Reformasi, Jakarta: Sekretariat Jenderal dan Kepaniteraan Mahkamah Konstitusi RI, page 66.
}

Formulation Article 24B paragraph (1) of the amendment of the 1945 constitution in particular phrase "other authorities" in order to preserve and uphold the honor, dignity and behavior of judges considered as provision multiple interpretations and unclear, so to "terminate" obscurity above the norm, the legislator No. 22 Year 2004 concerning Judicial Commission redefined the authority of the Judicial Commission.

The formulation of Article 13 paragraph (a) of Law Number 22 Year 2004 concerning Judicial Commission in the implementation is not create a debate and controversy. This is different when the Law Number 22 Year 2004 concerning Judicial Commission "trying" to clarify the authorities of the other in order to keep the nobleness and dignity also behavior of judges. This can be seen from the provisions of Article 20 of Law Number 22 of 2004 which determines that: In exercising the authority referred to Article 13 letter $b$ of the Judicial Commission has the task of monitoring the behavior of judges in order to uphold the honor and dignity and maintain behavior of judges.

Under the provisions of Article 20, it can be concluded that in the perspective of lawmakers, one of the ways that can be done by the Judicial Commission in order to implement the provisions of Article 24B of the 1945 Constitution is by providing authority to the Judicial Commission to oversee the conduct of judges. The legal substance of article 24B paragraph (1) of the 1945 constitution are: first, to maintain the honor of the judges; second, maintain the dignity of judges; third, maintain the behavior of judges; fourth, to uphold the honor of judges; fifth, to uphold the majesty, honor of the judge and sixth, enforce the judge's behavior. In a word maintain contained the sense of preventive measures, while the word definition uphold contained corrective behavior, since the first, 3 (three) authorization is preventive or prophylactic, while the second, 3 (three) authorization actions are corrective authority. ${ }^{6}$

However, the provisions of Article 13 (b) of Law Number 22 Year 2004 relating with the

6 Ibid, page 194. 
formulation of Judicial authority is changed to "uphold the honor and dignity also keep the behavior of judges. If it is elaborated into a narrower scope, there are only (1) uphold the honor of the judges, (2) upholding the dignity of judges, (3) maintain the behavior of judges. From here it can be said that the former Act intentionally limiting the definition contained Article 24B paragraph (1) the 1945 Constitution. The authority of a preventive nature only associated with efforts to maintain the behavior of judges, while corrective only associated with efforts to uphold the honor and dignity of judges. ${ }^{7}$ Based on these descriptions, then there has been a "degradation" of the substance of the charge between mandated in Article 24B paragraph (1) of the 1945 Constitution with organic legislation.

The existence of Judicial Commission in order to support the creation of a judiciary that can truly reflect as a judiciary to uphold the law and justice, and therefore the authority of the Judicial Commission, essentially to answer pessimism and mistrust of the world community towards justice. Disharmony relationship happens between the Supreme Court and the Judicial Commission to some extent has led to "delays" efforts to achieve a clean judiciary and quality, and free from the influence of government and other powers, including the power of money and politics. ${ }^{8}$

The request of judicial review of Law Number 22 Year 2004 in fact questioning the juridical and logical connection between the legislation and the constitution, meaning the application in the perspective of the official wanted to test whether the Law Number 22 Year 2003 in accordance with the 1945 Constitution as the supreme written law, where laws and regulations under it must be aligned and a further reflection of the spirit and soul of the 1945 Constitution, however, can be understood by the public that the applicant's reasoning is packaged in the form

\footnotetext{
7 Ibid, page 196.

8 Muhammad Fauzan, "Pasang Surut Hubungan Antara Mahkamah Agung dengan Komisi Yudisial Dalam Sistematika Ketatanegaraan republik Indonesia", Jurnal Dinamika Hukum, Vol. 12 No. 1, January 2012, Purwokerto: Faculty of Law Universitas Jenderal Soedirman, page 125.
}

of implementation of rights constitutional rights of the 31 justices who individually or personally feel violated his constitutional rights, the applicant also requested the interpretation of the clarity of the meaning of the word "judge" in Article 24B of the 1945 Constitution.

On the basis of this argument, the applicant argues that they as the justices is not a judge who is meant by the word "judge" in Article $24 \mathrm{~B}$ of the 1945 Constitution, therefore, the actions of the Judicial Commission oversees justices, and the provisions of the Law Number 22 Year 2004 related to supervisory, should be declared contrary to the constitution. Further reason, the term "judge" "does not include constitutional justice". 9

Associated with the request that the judges in Article 24B paragraph (1) of the 1945 Constitution, not including Supreme Court justices by the Constitutional Court has been dismissed by stating that: "...the petition if related to supreme court there is no enough enough to grant it". In other parts of the Constitutional Court Number 005/PUU-IV/2006 stated that Law Number 22 Year 2004 proved not detailed governing supervisory procedures, unclear and unambiguously determine who oversees the subject, object of the supervision, instruments to be used, and how the process of supervision was implemented. ${ }^{10}$

The verdict based on author's opinion is a solution that is "offered" by the Constitutional Court to end the "deadlock" and "uncertainty" of the Judicial Commission in performing basic tasks and monitoring functions, particularly the function of supervision over the conduct of judges. The Judicial Commission's confusion in implementing main task and function, as well as to "terminate" disharmony relationship between the Supreme Court by the Judicial Commission, Parliament and the government has issued Law Number 18 Year 2011 on Amendment to Law Number 22 Year 2004 concerning Judicial Commission, based on the provisions of Law Number

\footnotetext{
9 Mohammad Fajrul Falaakh, MA-MK-KY Kekaburan Konstitusi, http://www.unisosdem.org/article_detail.php?aid= 6563 \& coid=3\&caid=21\&gid=3, downloaded on December $3^{\text {rd }} 2011$.

10 Ibid.
} 
18 Year 2011, the authority of the Judicial Commission experienced a reinforcement. ${ }^{11}$

Following up the Constitutional Court decision Number 005/PUU-IV/2006 and to avoid any conflict of laws governing authority to supervise, then there are Law Number 3 Year 2009 concerning the Supreme Court, Law Number 48 Year 2009 concerning the Powers of Judicial, and Law Number 18 Year 2011. Law Number 3 Year 2009 concerning Supreme Court and Law Number 49 Year 2009 concerning Judicial Power and Law Number 18 Year 2011 concerning Amendment to Law Number 22 Year 2004 concerning Judicial Commission, essentially a compromise and means "peace" who "initiated" by the Constitutional Court that "forces" the President and Parliament to set up a law to put an end to a conflict between the supervisory authority of the behavior of judges of the Supreme Court and the Judicial Commission.

Under Law Number 3 Year 2009 concerning the Second Amendment to Law Number 14 Year 1985 concerning Supreme Court, stated that in addition to the Judicial Commission, the Supreme Court also given the authority to supervise the legal behavior, it is stipulated in Article 32A paragraph (1) and (2) which provides that: "Internal supervision over the behavior of Supreme Court justices is done by the Supreme Court. External supervision over the behavior of Supreme Court justices is done by the Judicial Commission. "While based on Law 48 Year 2009 concerning Judicial Power, supervision behavior of judges conducted by the Supreme Court and the Judicial Commission. It is as mandated in Article 39 paragraph (3) which provides that: "Internal supervision over the behavior of judges conducted by the Supreme Court".

\section{Institutional Organization Problematic}

Other problematic supervision of the judge in a system of constitutional law is concerned with the institutional or organizational aspects. The aspects related to the position and number of commissioner personnel. Under Article 24B paragraph (4) of the 1945 Constitution Struc-

\footnotetext{
${ }^{11}$ Muhammad Fauzan, Pasang Surut..., op.cit., page 127.
}

ture, position and membership of the Judicial Commission shall be regulated by law. And as described above, that the implementation of the provisions of the article can be viewed with the enactment of Law Number 22 Year 2004, Law Number 18 Year 2011 concerning Amendments to Law Number 22 Year 2004 concerning Judicial Commission.

According to Article 3 of Law Number 22 Year 2004, Judicial Commission position exists only in the state capital, with the number of commissioners under Article 6 paragraph (1) amounted to 7 (seven) people. Position Judicial Commission, which only exists in the state capital and only 7 (seven) members have been predicted that the Judicial Commission would not be able to perform basic tasks and functions in order to preserve and uphold the nobility, dignity and behavior of judges, as mandated in Article 24B paragraph (1) the 1945 Constitution.

Rationality is not balanced between the number of commissioners of the Judicial Commission with the number of judges to be monitored as well as the vast area of the country where judges are scattered across the country, of course, it may affect on the effectiveness of supervision. Data shows that the number of judges of first instance courts judges to justices totaling approximately 7.708 judges with following details judges in supreme justice including Chief Justice $=142$, general Courts of Appeal $=$ 503 people, First Level $=3.171$ people, the Religious Court Appellate $=492$ and First level $=$ 3,009 people, the Military Courts of Appeal $=12$ and $=79$ the first level, the Administrative Court of Appeal $=39$ and First level $=261$ people. ${ }^{12}$

Based on these data, we can conclude that Comparison ratio between the number of commissioners of the Judicial Commission with the number of judges who will be watched an average of 1 (one) commissioner Judicial Commission shall supervise the behavior of the 110 judges who are spread throughout the country. To achieve the optimization of the implementation of the authority supervising judges are not comparable with the number of commissioners

\footnotetext{
${ }^{12}$ Annual Report of Supreme Court in 2013, page 20 and 146
} 
of the Judicial Commission, the Law No. 18 of 2011 gives the right to the Judicial Commission to recruit liaison. It is as mandated in Article 3 paragraph (2) and (3) which provides that:

(2) Judicial commission could recruit link in the area as needed.

(3) Further provisions about the formation, composition, and system work link Judicial Commission in the area referred to paragraph (2) is regulated by the Judicial Commission.

The presence of Judicial Commission liaison with the number of 34 people according to the number of provinces and domiciled in the Capital at certain level has been a bit much to overcome the limitations of the commissioners to obtain data and information on the behavior of judges in the area. Apart from the question of liaison does not have the authority as well as commissioners of the Judicial Commission but in the execution of their duties indicates that the link has managed to become an agent which provides information on the public reports related to alleged code of ethics and code of conduct of judges. It can be seen from the annual report of the Judicial Commission and the documents of 9 (nine) year existence of Judicial Commission since 2005 up to April 2014 there were at least 10.455 complaints/reports, either already registered or have not registered yet and the online registration.

\section{Supervision Understanding Problematic Adop- ted in Legislation}

Other juridical problematic with regard to the supervision of judges in the system of constitutional law, namely the lack of clarity about the definition of "supervision". Both the 1945 Constitution and Law Number 22 of 2004 about the Supervision, and Law Number 18 Year 2011 on Amendment to Law Number 22 Year 2004 concerning Judicial Commission does not impose limits on the term "supervision".

Both laws only provide information about how monitoring is done. That is as may be inferred from the provisions of Article 22, which specifies that the: first, in implementing the supervision Judicial Commission accepts society's re- ports and/or information about alleged violations of the Code and/or the Judicial Code of Conduct; and second, to implement Judicial Commission supervision can request information or data to Judicial institution and/or Judge.

Actually, it should be understood that the presence of the Judicial Commission as an external supervisory institution of judicial power, is to involve Indonesian society outside the formal structure of the parliamentary institution in the process of appointment, performance assessment and possible dismissal of judges. It is expected to be realized judiciary independent and impartial by nature (independent and impartial judicary) which also offset by the principles of accountability, KY presence gives new hope for justice seekers to realize the clean and respectable judiciary. ${ }^{13}$

There are concerns that the authority to supervise the conduct of judges by the Judicial Commission could harm the autonomy and independence of judges, whereas the autonomy and independence of judges is a "crown" of independent judicial power. The principle that the judicial power is a principle that is universal and applicable throughout the world, especially the countries that apply the principles of a constitutional state.

Noting this, the understanding of the meaning of "control" becomes important. As noted above, that one of the juridical problematic in the implementation of the supervision of judges, due to the absence of a common understanding of the term "supervision". The 1945 amendment did not pose a limitation on the term "supervision", it does not give a definition of the term, the term "supervision is absolutely nothing in the regulations concerning the duties and authority of the Judicial Commission.

Supervision by Imam Al Ghazali in Islamic law is "the greatest pole". While George R.Terry stated that Control is determine what is accomplished, evaluate it, and apply corrective meas-

\footnotetext{
${ }^{13}$ Devica Rully Masrur, "Implikasi Putusan Mahkamah Konstitusi Dalam Pengujian UU No. 22 Tahun 2004 Tentang Komisi Yudisial Terhadap Pengawasan Perilaku Hakim", Jurnal Hukum Kebijakan Publik RES REPUBLICA, Vol. 1 No. 1, September 2007, Surakarta: Universitas Sebelas Maret, page 25.
} 
ures, if needed to ensure result in keeping with the plan (supervision determine what has been achieved, evaluate and implement corrective action, if necessary to make sure the results which according to the plan). ${ }^{14}$ While Muchsan said that oversight is an activity to assess the implementation of the tasks de facto, while the objective of supervision is limited to matching what activity has been carried out in accordance with the benchmarks previously set. In connection with the terms of supervision, Bagir manan found "control" as a function and the right so commonly known as control functions or control rights. Control contains dimensional monitoring and control. Supervision related to directives (directive). In the other side the others expert argue that supervision is an attempt to avoid the occurrence of errors, either intentionally or unintentionally, as preventive measures, or even attempt to fix when it goes wrong it as repressive efforts. ${ }^{15}$

Based on the above description, it means that supervision basically is an activity performed in order to determine whether an activity or program or action is in accordance with the plan that has been determined, or in accordance with the regulations, an attempt to avoid the occurrence of irregularities or errors and trying to fix the mistakes that occur. In connection with the supervision of the conduct of judges, the authors argue that supervision is an activity that is conducted in a structured or systematically carried out by the Judicial Commission in order to determine and ensure that the judge's behavior both in order to carry out the duties and functions of law enforcement and also as the members of society remains appropriate with norms and ethics in society.

The importance of the supervision of jud ges is partly due to the judge even said to be the "Vice of God" in the world, however, as people in general, judges will not escape from er-

\footnotetext{
${ }^{14}$ Farid Abdul Khaliq in Ni'matul Huda, Fi Al-Fiqh As-Syiasiy Al-Islami Mabadi Dusturriyyah As-Syura Al-'Adl Al-Musyawah, Translated by Faturrahman A.Hamid with the tittle Fiqih Politik Islam, Amzah, Jakarta, 2005. See also Yus ran, Pengawasan Hakin dan Akuntabilitas Peradilan, Varia Peradilan, Year XXX No. 354 May 2015, page 119

15 Ibid, page 129
}

rors, either in judgment, and in the running life and livelihood. Noting this, the judge as a key pillar for the enforcement of the law and justice will not be separated from the norms and rules in social life, including in carrying out its duties and functions as the court, thus the supervision of a judge to continue on the right track have high urgency, only to note that in the implementation of supervision does not affect the independence and freedom of judges. Supervision conducted only limited on things that are not related to the judicial technically, because the technical supervision relating to judicial becomes the authority of the Supreme Court.

Based on the above description it can be said that the activities of implementation of the Judicial Commission's task in carrying out its duties, particularly the duty to supervise the behavior of judges in order to keep the nobleness and dignity of judges, there should be a guarantee that in the implementation of Judicial Commission's task only in the "realm of" non-judicial, should not be entered the judicial area, therefore the formulation of the provisions of Article 24B paragraph (1) of the 1945 Constitution, particularly the judicial Commission sentence... the honor, dignity, and the behavior of judges, there are really only at the level of ethical behavior.

Supreme Court Justice Dudu Duswara in a chance to say that he agrees, that the judge should also be monitored, and the Judicial Commission should be strengthened, only to note that in the implementation of the duties and supervision authority, should still be required coordination with the Supreme Court, so that the impression that the Commission judicial has a higher position than the Supreme Court can be avoided, this will occur is strongly influenced by the pattern of commissioner leadership of judicial Commission. ${ }^{16}$

\section{Conclusion}

Based on the description and discussion above it can be concluded that in carrying out the functions of supervision of judges by the

\footnotetext{
${ }^{16}$ An interview with Supreme Court Judge Dudu Duswara, on September 2015
} 
Judicial Commission, there are several problematic juridical include: first, the unclear formulation of Article 24B of the 1945 Constitution, especially with regard to other authority of the Judicial Commission in order to preserve and uphold the honor, dignity, as well as the behavior of judges; second, with regard to disharmony and inconsistency of the laws which regulate the supervision of judges; third, with regard to the institutional organization of the Judicial Commission; and the fourth, with regard to the unclear definition of supervision.

\section{Suggestion}

In order to optimize the implementation of the basic tasks and functions of the Judicial Commission, as well as to realize the harmonization of the harmonious relationship between the supervisory agencies of judges, it is recommended as follows: first, a need for a clear meaning of the notion supervisory judge's behavior, so it will not arouse suspicion that the supervision conducted would harm the principle of independent judicial power and the independence and freedom of judges; secondly, should be a reformulation associated with the provision of Article 24B paragraph (1) of the 1945 Constitution of the amendment, especially relating to sentences of other authorities in order to preserve and uphold the honor, dignity, and behavior judges.

\section{References}

Asshiddiqie, Jimly. 2006. Perkembangan dan Konsolidasi Lembaga Negara Pasca Reformasi. Jakarta: Sekretariat Jenderal dan Kepaniteraan Mahkamah Konstitusi RI;

Fauzan, Muhammad. "Pasang SurutHubungan Antara Mahkamah Agung dengan Komisi Yudisial Dalam Sistematika Ketatanegara- an republik Indonesia". Jurnal Dinamika Hukum. Vol. 12 No. 1. January 2012. Purwokerto: Faculty of Law Universitas Jenderal Soedirman;

Gultom, Binsar M. "Hormati Independensi Badan Peradilan". Varia Peradilan Majalah Hukum. Year XXX No. 350. January 2015. Jakarta: IKAHI;

Kelsen, Hans. Pure Theory of Law. 1967. Page 313 in Denny Indrayana. "Negara Hukum Indonesia Pasca Soeharto: Transisi Menuju Demokrasi vs Korupsi”. Jurnal Konstitusi. Vol. 1 No. 1. July 2004. Jakarta: Constitutional Court;

Khaliq, Farid Abdul. 2005. Fi Al-Fiqh As-Syiasiy Al-Islami Mabadi Dusturriyyah As-Syura Al'Adl Al-Musyawah. Translated by Faturrahman A.Hamid. Fiqih Politik Islam. Jakarta: Amzah.

Annual Report of Supreme Court in 2013. Page 20 and 146

Masrur, Devica Rully. "Implikasi Putusan Mahkamah Konstitusi Dalam Pengujian UU No. 22 Tahun 2004 Tentang Komisi Yudisial Terhadap Pengawasan Perilaku Hakim". Jurnal Hukum Kebijakan Publik RES REPUBLICA. Vol. 1 No. 1. September 2007. Surakarta: Universitas Sebelas Maret;

Mohammad Fajrul Falaakh. MA-MK-KY Kekaburan Konstitusi. http://www.unisosdem.org/ article_detail.php?aid=6563\&coid=3\&caid $=21 \mathrm{kgid}=3$. Downloaded on December $3^{\text {rd }}$ 2011.

Nurhadi. "Bunga Rampai: Independesi Peradilan dan Imunitas Yudisial Hakim Yang Terancam". Varia Peradilan Majalah Hukum. Year XXVII No. 331 June 2013. Jakarta: IKAHI. 2013;

Suseno, Franz Magnis. 1993. Etika Politik: Prinsip Moral Dasar Kenegaraan Modern. Jakarta: Gramedia;

Yusran. "Pengawasan Hakin dan Akuntabilitas Peradilan”. Varia Peradilan. Year XXX No. 354. May 2015. 